\title{
Social Media Makes Things Possible For Librarians: A Critical Note
}

\author{
Muhammad Anwar*1 and Tang Zhiwei ${ }^{2}$ \\ ${ }^{1}$ Scholar School of Management and Economic, UESTC, University of Balochista, China \\ ${ }^{2}$ School of Political Science and Public Administration, UESTC, University of Balochista, China
}

*Corresponding author: Muhammad Anwar, Scholar School of Management and Economic, UESTC, University of Balochista, China.

To Cite This Article: Muhammad Anwar. Social Media Makes Things Possible For Librarians: A Critical Note. Am J Biomed Sci \& Res. 2019 - 6(1). AJBSR.MS.ID.000985. DOI: 10.34297/AJBSR.2019.06.000985.

Received: 溜 October 11, 2019; Published: 眥 October 30, 2019

\begin{abstract}
The rapid progress and development of social media and its associated tools have made things easy for the library staff and library professionals. Social media is the fastest tool of communication in today's world, where everyone can reach the other within a click. At the same time, the library professionals are getting familiar with social media and its related tools to apply in their respective libraries. The library professionals are creating a virtual platform using Social media to interact with their users and social media is also helping to reach out to the targeted audiences and customers. Social media is using by librarians to make their library users and also use social media for the marketing of their sources and services. Several factors are influencing the use of social media in the libraries because the library professionals think that social media is the best choice to bring library users nearer. Besides these facts there are massive numbers of challenges and issues are facing by the library professional while using social media in their respective libraries. These hurdles and issues should be resolved for better and reliable use of social media in the libraries. Library professionals use social media to share information with their potential users. This paper has highlighted some of the aspects of social media e.g. usage, factors and issues, challenges in the use of libraries.
\end{abstract}

Keywords: Social media, Librarians, Digital, ICTs, Network

\section{Introduction}

The present age of the digital world has changed the course of the individual and collective thinking of the people as well as the mindset of the service providers. The rapid growth of ICTs and its associated aids has changed the living standard of human beings. ICTs made several revaluations in term of social media and others same media of communications.at the beginning of computer and internet the people thought that this is biggest things to use for their lifelong working but at the inception of social media, the people saw a massive change in the mode of communication. Social media makes things easy to connect, share and receive information from one end to another end of the world. Even though this media of communication has changed attitude, thinking and perception of service providers throughout the globe.

[1] agreed that social media has finished the discrimination of communication from the community and it provides the way to access the learned society and make them aware of the access to the library sources and services from their home. Moreover, social media is providing the techniques to the librarians to make things easy to market their sources and services to their targeted audiences. These social media are [2,3], LinkedIn, My Space, web.2.0 [4], Blogs, WhatsApps [5], QQ and Wechat [6] and LIS professionals are using these social media to interact with their users at remote locations and marketing their products [7] addressed that twitter is the type of social media that allows the library professionals to create a platform to access library resources and services. Additionally, the Library Professionals are trying to use a suitable and convenient means of communication to fulfill the needs and wants of library users.

The number of libraries in the world is using different social media to bring library users to nearer library sources and services. [8] found that Librarians are using social media for professional development in their respected areas of interest. Moreover, the present age social networking sites are meeting the need of library professionals to prepare themselves for upcoming challenges in their fields. Library professionals should learn skills and knowledge to develop them to meet the needs and wants of the library users in the future. $[9,10]$ added that social networking technologies 
are creating a virtual environment changing the method of communication among library users and library professionals. Furthermore, in the current age of social media usage, library professionals are getting familiar with the demand of library users.
On the other hand, the utilization and adoption of social media in the libraries are making a big difference to cope up with the issues and challenges shortly. Facebook is the most popular network amongst librarians, followed by Twitter and blogs (Figure 1).

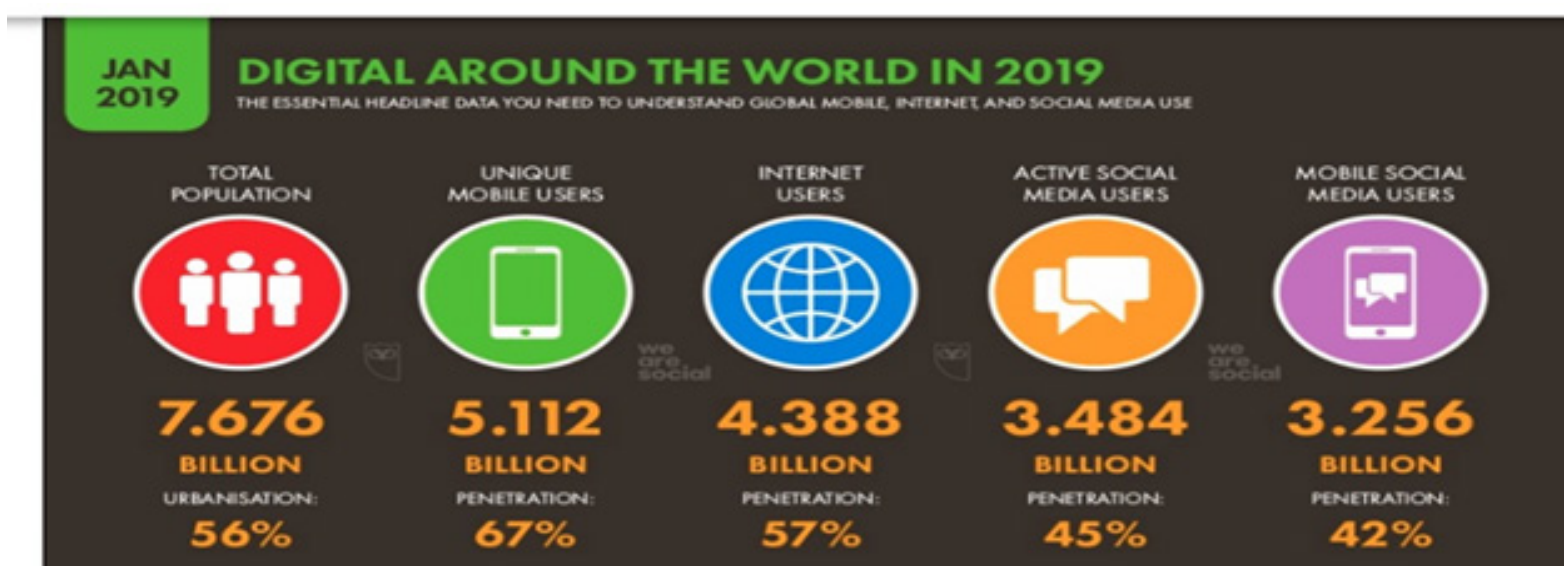

Figure 1: Source: https://www.smartinsights.com/social-media-marketing/social-media-strategy/new-global-social-media-research.

\section{Social Networks Sites}

The present age of information explosion has encountered the mindset and thinking of human beings. Everyone is running behind the information, but they have no idea how to collect the information and shared the information from one to one and one to many at one time. Besides these facts, the present age of information ICTs and its related aids has changed the role of information professionals. Furthermore, ICTs has made tremendous achievement in the shape of generating the social networks sites for exchanging the information one end to another end. According to Wikipedia (2019) "Social media may have roots in the 1840s introduction of the telegraph, which connected the United States". Social media has created an environment where everyone can access the information, share the information and disseminate the information. Additionally, there is a number of social networks has been launched and some of them are very much popular throughout the globe like Facebook, Twitter, YouTube, WeChat, Instagram, QQ, QZone, Weibo, Twitter, Tumblr, Telegram, Baidu Tieba, LinkedIn, LINE, Snapchat, Pinterest, Viber etc. social media creates an effective platform to make people access and share their information with other people with far distance. Social media helps the library professionals to make things easy for them and for their readers to increase their capacity to build good relationships among library staff and library users. Social media like Facebook helps the library professionals to create an account to promote their library sources and services. Facebook provides platforms to market their source s and service effectively and efficiently.

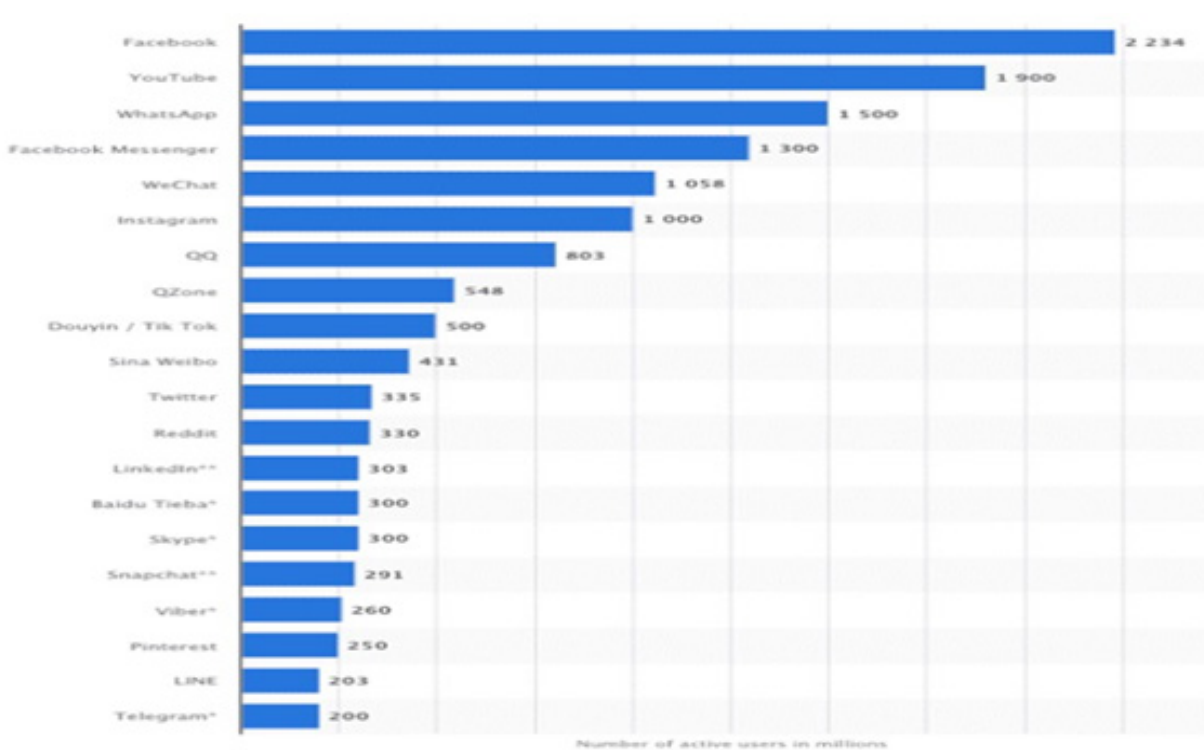

Figure 2: Source: https://www.smartinsights.com/social-media-marketing/social-media-strategy/new-global-social-media-research. 
Likewise, Twitter is playing a vital role in the promotion of library sources and services. [11] today in the modern age of ICTs the social media is the cheapest source for marketing the library sources and services. Additionally, Social media have a different aspect to share news and views about the library, communicate different events and create an environment for effective service to their library users [12] addressed Facebook is the best tool to promote library sources and services and provides a platform to market library sources and services with low expenditures. Furthermore, Facebook helps the library staff to advertise their product and maximize the use of their sources and services to the potential users (Figure 2).

\section{Definition of social media}

1. Social media is a collection of Internet-based communities that allow users to interact with each other online. This includes web forums, wikis, and user-generated content (UGC) websites.

2. Websites and computer programs that allow people to communicate and share information on the internet using a computer or mobile phone.

\section{Definition of facebook}

1. Facebook is a popular free social networking website that allows registered users to create profiles, upload photos, and video, send messages and keep in touch with friends, family, and colleagues.

2. An online community that allows individual users to create personal profiles, share photos and videos, and post on each other's profile pages, or "Timelines."

\section{Definition of twitter}

3. An Internet service that allows people to publish quick updates and see posts or "tweets" of other users they are following in real-time.

of LinkedIn

4. A professional networking website that allows users to create profiles, post resumes, and communicate with other professionals and job-seekers of Pinterest.

5. An online community that allows users to share ideas and photos with others by "pinning" items and describing them on their profile pages.

\section{Definition of mySpace}

6. My Space is an online community that allows friends to keep in touch and meet new people as well. It started as a website that bands could use to promote their music but has since grown into a more general community of friends.

\section{Definition of instagram}

1. Instagram is an online photo-sharing service. It allows you to apply different types of photo filters to your pictures with a single click, and then share them with others.

\section{Definition of blog}

1. Short for "Web Log," this term refers to a list of journal entries posted on a Web page. Anybody who knows how to create and publish a Web page can publish their blog.

\section{Definition of wikis}

1. A wiki is a Web site that allows users to add and update content on the site using their Web browser.

\section{Definition of web 2.0}

1. Web 2.0 is a term that was introduced in 2004 and refers to the second generation of the World Wide Web.

\section{Definition of twitter}

1. Twitter is a microblogging and social networking service on which users post and interacts with messages known as "tweets". Tweets.

\section{Related works}

[13] addressed librarians' awareness of social media usage for informal scientific communication in university libraries in south-south, Nigeria. The author used the survey method and questionnaire to collect the data and descriptive research method. He has collected data from 284 librarians. The response ratio of the research was $71 \%$ because out of 284 respondents 202 were retrieved with proper responses. The result of this study has revealed that the majority of the librarians were fully aware of the use of social media. On the bases of these findings, the author has suggested that the library administrator should provide the social media tools for better communication and librarians should be well aware of the importance of social media while in communicating.

[14] investigated the influence of social networking sites on library and information centers. They focused on the latest development in the library and information centers in terms of information transformation. They find out that the present age every library is connected with a different type of social media to maximize the gape among libraries and users. They mentioned some of the most popular social media like Facebook and twitter etc. $[15,16]$ examined the social networking technologies in the digital environment: its possible implications on libraries. $\mathrm{He}$ investigated that social networking sites are making things easy for library users to interact with other library users to get connected to the world using the web. He examined different social software and their usage in the libraries but finally, the author has found out the web 2.0 is suitable social software for the libraries to interact with their users.

[17] studied how libraries use social networking sites to interact with users. They probed that the adoption of social networking sites is increasing day by day at a great pace. They further added that besides these facts the participation of the library users to the social networking sites is very little. They investigated some major social network sites Facebook, Twitter and Weibo about the sharing, 
dissemination, communication, and gathering of knowledge and information. They used mix methods to complete this research. The authors have found out 1700 posts from 40 libraries SNS and interviewed 10 librarians.

$[18,19]$ surveyed the librarian's use of social media for professional development in Nigeria. He investigated some 1294 registered members of the Nigerian Library Association online forum and he has selected 297 respondents for this study. The questionnaire was used to collect data from online social network users like Facebook, wikis, and podcasts. He has concluded the findings that the majority of the librarians in Nigeria were taking interest in professional development via social media.

\section{Factors of Usage of Social Media in the Libraries}

The social media is playing a pivotal role to reach out the potential customer and users. The massive number of information has been transferred from the last four to five decades from one pole to the other pole of the world. The social media is the biggest change of the 21st century and it is growing rapidly. Millions of information are being shared one to one, one to many at the same time on the same channels. The libraries are looking forward to using social media to fulfill the requirement of their users. Social media gained several factors of usage in the libraries to disseminate the information within a quick time. [20] some of the purposes that meet the library user's needs and this will help to reach out to the new customers. Furthermore, he discussed that social media build library image and modernize the library.

[21] mentioned that social media is the technique or tool to make things easy and it is the vital source to share and receive the information. Facebook is the best tool to accommodate strong positive impact SMEs and positive relations with the non-financial performance of SMEs [22] Social media is providing the best tool to reach library users where they can share and receive their information without any trouble. Additionally, social media is putting a great impact on libraries. LIS professionals are getting familiar with social media to create a flexible environment to reach potential library users. [23] social media is putting a massive impact on libraries and information centers to promote library services and sources. Several social media bring all the library users community together on one spot to share their ideas and views about their relevant and specific information. Furthermore, social media is providing massive space to the library professionals to create a virtual environment to enhance the library service providing capacity. [24] addressed that the use of social media is making things easy for library professionals to reduce the gap between library users and library resources and services. Moreover, social media is expanding their use in the libraries because of the library uses approach [25] have given remarks about the social media that this will facilitate the library professionals to achieve their library goals and objectives.

Likewise, social media will help library professionals to make their services effective and efficient. Social media will establish a bridge between library users and library resources. Similarly, the fourth law of library sciences told about the saving of time of library users. So, the present age of ICTs social media is a powerful tool to engage the library users from remote locations to the library resources and services. It can be said the there are number of factors of using social media in the libraries and information centers. so, those factors can be interaction with potential library users, marketing of library sources and services, sharing and receiving the information, searching for new library users, save the time of library users, achieve the library goals and objectives, create an effective environment, improve the library images, etc (Figure 3).

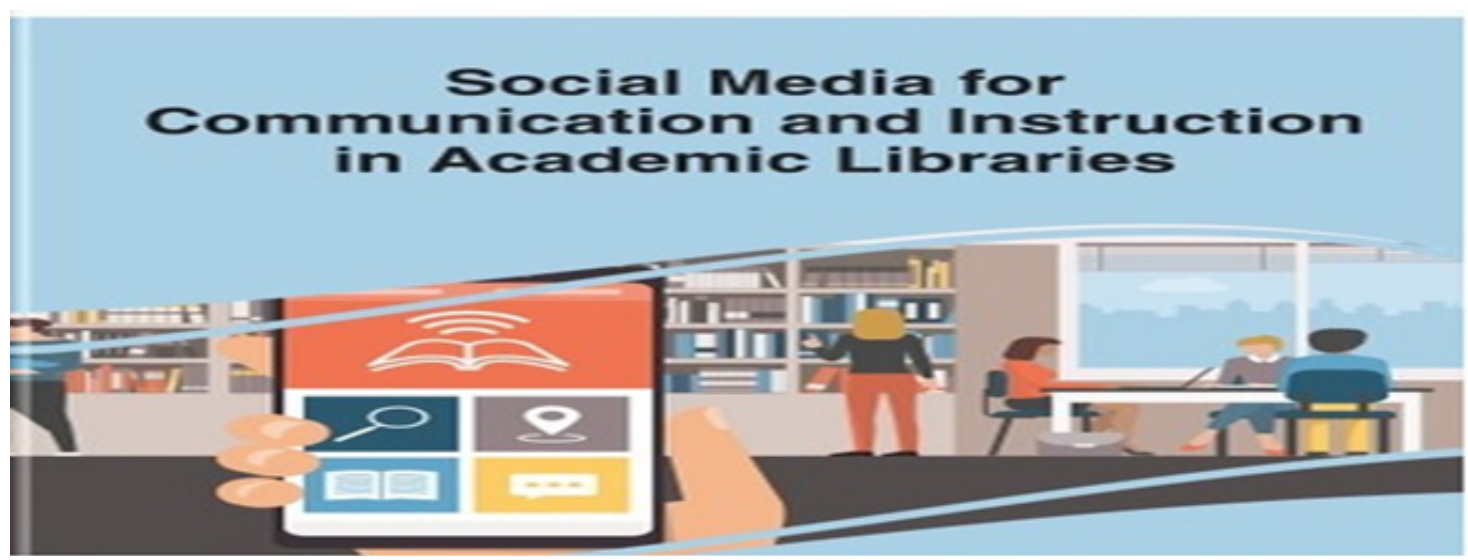

Figure 3: Sources: https://www.kobo.com/gr/en/ebook/social-media-for-communication-and-instruction-in-academic-libraries

\section{Issues and Challenges use of Social Media in} Libraries

[26] investigated the challenges at the usage of social media in the Nigerian university libraries. They indicated some of the major issues and challenges that are creating problems with the use of social media in the said study population. They mentioned some of them as follows lack of financial support, lack of authority support, lack of cooperation among the library staff, no knowledge of social 
media and its tools and lack of expertise of ICTs and lack of getting feedback from library users. Furthermore, it can be said that these challenges are genuine that encountering the use of social media in libraries throughout the globe. Today, the world has become a global village and everyone is access to the internet connecting to other people via social media. The librarians and LIS professionals are trying to make a bridge between the library sources, services and library users via social networks. [27] addressed the challenges of the use of social networking sites in the libraries. They identified some of the challenges and issues of lack of training of library staff, lack of government or authority supports copyright issues. Furthermore more, these issues should be resolved until the librarians cannot use social media for the promotion of library sources and services.

\section{Conclusion}

The recent past social media growth comes at the peak. Social media is the most promising tool to interact with other remote located peoples. Besides these facts, social media are providing a new and excellent platform to the library professionals to reach out to their potential library customers to fulfill their needs, wants and demands. Social media is the point of access where every individual library users can get their demand within a click [28] addressed social networking sites are the technologies that are offering new methods of access to latent customers. Likewise, social media helps the librarians to make their services effective and convenient. The most popular social media like Facebook, Twitter, LinkedIn, and Wechat are the best tools for library staff to promote their library services and sources [29] make their opinion about web 2.0 that the majority of the libraries are applying this social media tool to share and provide information services to their online clients. Furthermore, librarians are personally taking an interest in using social media to bring people to know about their sources and services. [30] searched the marketing library services through Facebook groups. Library staff is using social media for the marketing of library sources and services. Social media can be a better choice for the library to adopt these tools and make them [31-33] accessible through the globe. Social media would play an important role to change the role and responsibilities of the librarians what we called today cyprian.it would be suggested that every librarian is to apply social media to promote their sources and services [34-37].

\section{Future Research Direction}

1. It would be better to research social media popularity among library professionals

2. It is suggested to work on social media can be fruitful for the libraries in the future generation.

\section{References}

1. Magoi JS, Aspura MYI, Abrizah A (2019) Social media engagement in developing countries: Boon or bane for academic libraries?. Information Development 35(3): 374-387.
2. Xia ZD (2009) Marketing library services through Facebook groups. Library management 30(6/7): 469-478.

3. (2014) Twitter

4. Verma MK, Verma NK (2015) Use of Web 2.0 technology by the central universities of India: A survey. In International Conference on the Convergence of Libraries, Archives and Museums: Innovative Ideas, Library Professional Association, New Delhi, India, pp. 59-69.

5. Purkayastha N, Chanda A (2018) WhatsApp means sharing information among Lis professional of North East India. A study. International Journal of Research in Applied 6(9): 69-82.

6. Sachin KV (2014) Impact of use of social networking sites on libraries. Knowledge Librarian 1(1): 116-124.

7. Zhang M, Sheu FR, hang Y (2018) Understanding twitter use by major LIS professional organisations in the United States. Journal of Information Science 44(2): 165-183.

8. Mishra C (2008) Social networking technologies (SITs) in digital environment: Its possible implications on libraries, India.

9. Mishra C (2008) Social networking technologies (SITs) in digital environment: Its possible implications on libraries, India.

10. Vatter Z (2016) Using social media for libraries. For the peace library system, p. 1-4.

11. Chan C (2012) Marketing the academic library with online social network advertising. Library Management 33(8/9): 479-489.

12. CLN OO (2018) Librarians'awareness of social media usage for informal scientific communication in university libraries in south-south, nigeria. Library Philosophy and Practice 1-35.

13. Prabhakar SV, Rani SVM (2017) Influence of social networking sites on library and information centres. International Journal of Library \& Information Science 6(1): 83-87.

14. Muruli N, Gireesh Kumar TK (2013) Marketing of library services and products through social media: An evaluation, India.

15. Onuoha UD (2013) Librarians' use of social media for professional development in Nigeria. Information Management and Business Review 5(3): 136-143.

16. Onuoha UD (2013) Librarians' use of social media for professional development in Nigeria. Information Management and Business Review 5(3): 136-143.

17. Sachin KV (2014) Impact of use of social networking sites on libraries. Knowledge Librarian 1(1): 116-124.

18. Ainin S, Parveen F, Moghavvemi S, Jaafar NI, Mohd Shuib NL, et al. (2015) Factors influencing the use of social media by SMEs and its performance outcomes. Industrial Management \& Data Systems 115(3): pp.570-588.

19. Magoi JS, Aspura MYI, Abrizah A (2019) Social media engagement in developing countries: Boon or bane for academic libraries?. Information Development35(3): pp.374-387.

20. Adewoyin O O, Onuoha UD, Ikonne CN (2017) Social media use and service delivery by librarians in federal universities in south-west, nigeria. Library Philosophy and Practice 1-14.

21. Dickson A, Holley R.P (2010) Social networking in academic libraries: the possibilities and the concerns. New library world 111(11/12): pp.468-479.

22. Ezeani CN, Igwesi U (2012) Using social media for dynamic library service delivery: The Nigeria experience. Library Philosophy and Practice 1.

23. Chu SKW Du, HS (2013) Social networking tools for academic libraries. Journal of librarianship and information science 45(1): pp.64-75.

24. Taylor \& Francis (2017) How libraries are applying social media. Content \& Communications Team, USA 
25. Social media.

26. Social media.

27. (2013) Social Media.

28. (2007) My Space.

29. (2014) Instagram.

30. Blog.

31. social media.
32. Wiki.

33. (2008) Web 2.0.

34. Taylor \& Francis (2017) How libraries are applying social media. Content \& Communications Team.

35. Social Media for Communication and Instruction in Academic Libraries. 36. Social Media Strategy.

37. Dave Chaffey (2019) Global social media research summary. 